\title{
THE COLONIAL PASTS OF MEDIEVAL TEXTS IN NORTHERN AFRICA: USEFUL KNOWLEDGE, PUBLICATION HISTORY, AND POLITICAL VIOLENCE IN COLONIAL AND POST-INDEPENDENCE ALGERIA*
}

\author{
Paul M. Love Jr \\ Al Akhawayn University
}

\begin{abstract}
This article argues that medieval Arabic texts that were published in colonial northern Africa constitute as much a part of the history of colonialism and its legacy as that of the medieval centuries in which they were written. Using the publication history of a medieval Ibadi text and its French translations, I demonstrate how texts like it were edited, translated, and published not only for academic purposes, but also as contributions to the production of 'useful' colonial knowledge in Algeria. I begin with the first translation, published in 1878 alongside other ethnographic and historical studies funded by the colonial state. I then turn to the second translation, serially published between 1960-2 as its editors abandoned the country at the violent end of the colonial period. Finally, I address the Arabic editions published after independence, which recast it within a nationalist framework. Overall, I argue for the importance of addressing the colonial pasts of medieval texts in northern Africa.
\end{abstract}

\section{Key Words}

Algeria, Tunisia, Morocco, North Africa, Sahara, text editions, material culture, colonialism, historiography, postcolonial.

Since its first publication in French translation under the title Chronique d'Abou Zakaria in I 878, the Arabic text known as the Kitāb al-sìra wa-akbbār al-a'imma (Book of the Lives and Accounts of the Imams) has served as an important source for writing the history of medieval northern Africa. ${ }^{\mathrm{I}}$ In particular, historians have treated this text as an indispensable guide to understanding the history of minority Ibadi Muslim communities in the early

\footnotetext{
* Research for this article was made possible in part thanks to the generous funding of the Social Sciences Research Council, the American Institute for Maghrib Studies, the Council for American Overseas Research Centers, and the Rackham School of Graduate Studies at the University of Michigan. I wish to thank Emma Park and Andrés Pletch for comments on a much earlier version of the article. Later revisions were enriched by discussions and suggestions for further reading by my colleague Derek Elliott at $\mathrm{Al}$ Akhawayn University. I also wish to acknowledge the tremendously helpful comments made by the two anonymous reviewers for $J A H$. Any shortcomings or errors in the final version are mine alone. Author's email: p.love@aui.ma

I E. Masqueray, Chronique d'Abou Zakaria (Algiers, I878).
} 
medieval period, the rise of the Fatimid Empire, and the early medieval history of Saharan trade connecting northern and western Africa. ${ }^{2}$ Yet the medieval contents of the printed text and its translations belie the much more recent colonial context that produced them. The two French translations of this text, published in I878 and I960-2, appeared at key moments in the history of the French colonial project in Algeria: the first was published only five years before the French took control of the Mzab valley and southern Algeria and the second appeared on the eve of Algerian independence. ${ }^{3}$ Not until more than a century after the publication of the first French translation did a full printed Arabic edition of the work appear in $1985 .{ }^{4}$

In this article, I follow the publication history of the Kitāb al-sìra and its French translations as a way of demonstrating that medieval Arabic texts that were edited and published in colonial northern Africa constitute as much a part of the history of colonialism and its legacy in the region as that of the medieval centuries in which they were written. ${ }^{5}$ In the process of being collected in manuscript form, edited, translated, and published, 'medieval' Arabic texts like the Kitäb al-sìra took on new meanings in each iteration of their publication history in late nineteenth and twentieth-century Algeria. In short, I use the example of

2 Ibadis are a Muslim minority community, who since the eighth century have lived in scattered settlements throughout northern Africa and the southeastern Arabian Peninsula. Neither Sunni nor Shi'i Muslims, Ibadis have long relied on their own textual corpora that distinguish them from their coreligionists. In the Middle Period (eleventh-sixteenth centuries), especially, Ibadis composed works of prosopography, theology, hadith, and law independent of other Muslim communities. For overviews of Ibadi history and doctrines, see A. Ennami, Studies in Ibādism (Benghazi, I972); P. Cuperly, Introduction à l'étude de l'ibādisme et de sa théologie (Algiers, I984); J. Wilkinson, Ibādism: Origins and Early Development in Oman (Oxford, 20I0); A. Gaiser, Muslims, Scholars, Soldiers: The Origins and Elaboration of the Ibādi Imamate Traditions (Oxford, 2010); V. Hoffman, The Essentials of Ibād̄ Islam (Syracuse, 20I2). Among works of scholarship on Maghribi Ibadis that utilized medieval sources including the Kitāb al-sìra and its translation by Masqueray, perhaps the best-known examples come from the corpus of work by the Polish historian Tadeusz Lewicki, who used them to write about many different aspects of the region's history. See, for example, T. Lewicki, 'Mélanges berbères-ibadites', Revue des Études Islamiques, 3 (I936), 267-85; T. Lewicki, 'Une langue romane oubliée de l'Afrique du Nord: observations d'un arabisant', Rocznik Orientalistyczny, I7 (I953), 4I5-80; T. Lewicki, Les ibadites en Tunisie au Moyen âge (Rome, I958); T. Lewicki, 'L'état nord-africain de Tahert et ses relations avec le Soudan occidental à la fin du VIIIe et au IXe siècle', Cahiers d'études africaines, 2:8 (I962), 5I3-35; T. Lewicki, Etudes Maghrebines et Soudanaises (Warsaw, I983). For a full bibliography, see K. Kościelniak, 'The contribution of Prof. Tadeusz Lewicki (1906-I992) to Islamic and West African Studies', Analecta Cracoviensia: Studia Philosophico-Theologica Edita a Professoribus Cracoviae, 44 (2012), 24I-55.

3 This second translation appeared in four parts, serialized in Revue Africaine: R. Letourneau, 'La Chronique d'Abū Zakariyyā' al-Wargalān̄̄', Revue Africaine, 462-3 (I960), 99-I76, 322-90; R. Letourneau, 'La Chronique d'Abū Zakariyyā' al-Wargalānī (Suite)', Revue Africaine, 465-5 (I96I), I I7-76; H. Idris, 'La Chronique d'Abū Zakariyyā' al-Wargalānī: deuxième partie', Revue Africaine, 468-9 (I96I), 323-74; H. Idris, 'La Chronique d'Abū Zakariyyā' al-Wargalānī: deuxième partie (suite)', Revue Africaine, 470-I (I962), II9-62.

4 An earlier printed addition of Part One of the work appeared in Algeria in I979: Kitāb siyar al-a'imma wa-akbbārihim, ed. I. al-'Arabī (Algiers, I979). A full printed edition of both parts was then published in Tunis six years later: Kitāb al-sìra wa-akhbār al-a'imma, ed. A. Ayyūb (Tunis, I985).

5 In what follows, I use the title 'Kitāb al-sìra' to refer to the text transmitted in the Arabic manuscript tradition from the Middle Period forward. When discussing the two printed editions of the text from the twentieth century, I distinguish them by using their published titles: Kitāb siyar al-a'imma wa-akbbāribim (I979) and Kitāb al-sìra wa-akbbār al-a'imma (I985). 
the various publications and forms of the Kitāb al-sìra and its French translations to shed light on the colonial pasts of medieval texts in northern Africa.

\section{THE KITĀB AL-SİRA WA-AKHBĀR AL-A IMMA}

For the seven centuries prior to the publication of the Chronique d'Abou Zakaria, the Ibadi Muslim scholars of medieval and early modern northern Africa knew this text in its original Arabic form as the Kitāb al-sìra wa-akbbār al-a'imma (The Book of the Lives and Accounts of the Imams). Although the oldest cataloged manuscript copy of the work dates to the fifteenth century, the Ibadi communities of the Maghrib have long attributed it to an eleventh-century scholar named Abū Zakarīyā' Yahyā b. Ab̄̄ Bakr al-Wārjalānī (d. I078 CE), whose name suggests he spent a significant amount of time in the medieval city of Wārjalān near the modern city of Ouargla in Algeria. ${ }^{6}$

The Kitāb al-sìra comprises two distinct parts, which may or may not have been compiled in the same period. Based on the date of scholars mentioned in the text, both halves appear to date to the mid-to-late eleventh century. ${ }^{7}$ The first relates the early history of Ibadi communities in the Maghrib, including an invaluable description of the history of the Ibadi Rustamid dynasty (748-909 CE) that ruled the city of Tâhart. ${ }^{8}$ Also crucial for historians of medieval northern Africa, the text provides an account of the Fatimid conquest of the Maghrib in the early tenth century and the subsequent revolt of the famous mid-tenth century apocalyptic Ibadi figure of the 'Man on the Donkey', Abū Yazīd 'al-Nukkārī.' The second part of the work offers biographical sketches and legal, moral, or miraculous anecdotes about Ibadi scholars and pious figures in the century and a half following the Fatimid conquest. ${ }^{\text {IO }}$ These anecdotes also contain a wealth of information about the Zirid dynasty that succeeded the

6 Based on a database of Ibadi prosopographical manuscripts in P. M. Love Jr, 'Writing a network, constructing a tradition: Ibāọ̄i prosopography in medieval northern Africa' (unpublished PhD thesis, University of Michigan, 20I6). Of the 23 copies of the Kitāb al-sirra in the database (as of January 20I5), the earliest dated copy is a fragment in the Âl Faḍl library in Benisguen, Algeria, dated 5 Dhū al-qa da 887/29 January I479.

7 Ibadi theologian and jurist Abū l-Qāsim al-Barrādī noted in the fourteenth century that the manuscript tradition of the Kitāb al-sīra comprised two parts: A. al-Barrādī, al-Jawāhir al-muntaquat fī itmām mā akhalla bihi kitāb al-țabaqāt [Litho.] (Cairo, I 884). Nevertheless, the manuscript tradition demonstrates that these halves often circulated independently of each other and overlapped with other manuscript traditions. See, for example, various debates in: A. al-Wisyānī, Kitāb siyar al-Wisyān̄ì, ed. U. Bū'așbāna, 3 vols. (Muscat, 2009); A. Amara, 'Remarques sur le recueil ibāḍite-wahbite Siyar al-Mashāyikh: retour sur son attribution', Andalus-Maghrib, I5 (2008), 3I-40; A. al-Wisyān̄̄, Siyar mashāyikh al-maghrib, ed. I. al-'Arabī (Algiers, I985).

8 On the Rustamids, see B. Bakīr, Al-dawla al-rustamīyya (Algiers, I985); Ibn al-Ṣaghīr, Akhbār al-a'imma al-rustumiyyīn, eds. M. Nāṣir and I. Baḥhāz (Beirut, I986); V. Prevost, L'aventure ibādite dans le sud tunisien, VIIIe-XIIIe siècle: effervescene d'une région méconnue (Helsinki, 2008); C. Aillet, 'Tāhart et les origines de l'imamat rustumide', Annales Islamologiques, 45 (20I I), 47-78; P. Love, 'Djerba and the limits of Rustamid power: considering the Ibāḍ̄ community of Djerba under the Rustamid Imāms of Tāhert (779-909 CE)', Al-Qantara, 33:2 (2012), 297-323.

9 M. Chapoutot-Remadi, 'Abū Yazīd Al-Nukkārī', Encyclopedia of Islam (3rd edn, 20I3).

Io On which, see Love, Writing a Network, 47-74. 
Fatimids, the beginnings of the spread of Arabic as a spoken language in the Maghrib, and the history of Saharan trade.

As a valuable historical source for the study of Ibadi history and the broader history of medieval northern Africa and the Sahara, the Kitāb al-sìra attracted the attention of colonial-era French historians already by the end of the nineteenth century. But the appearance of this work in translation owed its publication to something more than the utility of its content to historians of the medieval Maghrib.

\section{EMILE MASQUERAY AND THE CHRONIQUE D'ABOU ZAKARIA}

In his study of the misadventures of French ethnographer and linguist Emile Masqueray (d. I 894), Ouahmi Ould-Braham offers a detailed account of the steps that led to the Ibadi text known as the Kitāb al-sìra being edited, translated, and published as the

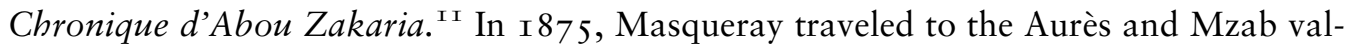
ley under the auspices of a mission financed by the minister of Public Instruction and the Governor General of Algeria 'to collect archaeological, linguistic, and ethnographic documents'. ${ }^{2}$ From the moment of his arrival in the Mzab valley and in the years following his time there, he relentlessly petitioned the French government and other potential sources of funding for financial support of his quest to gather and publish Ibadi texts from the area. ${ }^{\mathrm{I} 3}$

Masqueray initially encountered opposition in his efforts to access these texts from the Ibadi scholars in the towns of Ghardaia and Beni Isguen. At one point, he was told frankly by the Ibadi community in the latter town, 'Our history books are our private property.' 4 He nevertheless succeeded in obtaining several manuscripts. Some of these, as he proudly explained in a letter to his superior, he acquired through 'several ruses' and by capitalizing on the antagonistic relationship between the Ibadi scholars and students in the towns of Malika and Ghardaia. ${ }^{15}$ In other cases, accounts of Ibadi history were related to him by Ibadi scholars themselves. No less a figure than Amuhammad b. Yūsuf Ațfayyish (d. I9I4) - among the most influential Ibadi figures of the nineteenth century and known as $a l$-Qut $b$ ('the pole' of knowledge) - met with Masqueray and composed a text on Ibadi history for him. ${ }^{\text {I6 }}$ Likewise, he acquired a copy of the Kitāb al-sìra by enlisting the help of an unidentified 'young man, [a] fugitive thief but talented calligrapher' to copy it for him. ${ }^{\text {I7 }}$

I I O. Ould-Braham, 'Émile Masqueray au Mzab: à la recherche de livres ibâdites', Études et documents berbères, 9:2 (1993), 5-35.

I2 Ibid. 6. Masqueray himself begins his introduction by explaining the story behind its publication; Masqueray, Chronique d'Abou Zakaria, VII.

I3 Ould-Braham cites correspondence in which Masqueray noted that his goal in visiting the Mzab valley was to obtain 'ancient laws and Berber chronicles' (Ibid. 8-9).

I4 'Nos livres d'histoire sont notre propriété personnelle.' Masqueray, Chronique d'Abou Zakaria, IX. Quoted in Ould-Braham, 'Émile Masqueray au Mzab', ıо.

I 5 Ould-Braham, 'Émile Masqueray au Mzab', I4, 2 I.

I6 Muḥammad Șāliḥ Nāṣir Bābā'ammī (ed.), Mu'jam a lām al-ibādiyya (Dictionnaire des hommes illustres de l'Ibadisme, les hommes du Maghreb), Volume II (Beirut, 2000), 399-406.

I7 Masqueray added that a scholar ( $\operatorname{lerc})$ would have risked excommunication for providing him with a copy. Masqueray, Chronique d'Abou Zakaria, XIII. 
Ultimately, Masqueray came away with several manuscripts, which included the Kitāb al-sìra and several other important medieval and modern Ibadi works of history, jurisprudence, and theology. ${ }^{\text {I }}$

The story of Masqueray's acquisition of the Kitāb al-sìra and his publication of its translation, the Chronique d'Abou Zakaria, belongs to the broader history of the production of knowledge and its relationship to the exercise of colonial power in nineteenth-century northern Africa. ${ }^{19}$ In the decades following the 1830 French invasion of Algiers, a military administration governed this new colony. During the second half of the nineteenth century, the work of French ethnographers and linguists proved crucial to the production of knowledge about colonial subjects in Algeria. Abdelmajid Hannoum has highlighted the important role played by the Arab Bureau, an office of the military-run colonial administration in the nineteenth century, in producing linguistic and ethnographic studies to aid in the exercise of power in this early stage of French colonialism in the region. ${ }^{20}$ Hannoum's study echoes the earlier work of Bernard Cohn, whose Colonialism and its Forms of Knowledge argued that the production of knowledge was crucial for the exercise of British colonial power in India. 'Knowledge', Cohn wrote,

enable[d] the British to classify, categorize, and bound the vast social world that was India so that it could be controlled. These imperatives, elements in the larger colonial project, shaped the 'investigative modalities' devised by the British to collect the facts. ${ }^{2 I}$

As with the 'investigative modalities' of British-controlled India, French administrators and academics applied their own methods of collecting and organizing information about their colony in northern Africa. These data would then be 'transformed into usable forms such as published reports, statistical returns, histories, gazetteers, legal codes, and encyclopedias'. ${ }^{22}$ Applying this idea to colonial Algeria, George Trumbull IV has demonstrated how nineteenth-century ethnographic work cumulatively constructed an 'Empire of Facts', which produced 'cultural representations enforced through assertions of authenticity, generating "facts" [and] descriptions with the force of claims of truth." ${ }^{23}$ In this kind of 'ethnographic state', Trumbull argued, 'colonial ethnography served ... to produce usable texts'. ${ }^{24}$

I 8 Ould-Braham reproduces the text of another letter to Henri Duveyrier, at the time secretary of the Société de Géographie, in which he lists the works he obtained. Masqueray himself published this letter in the Bulletin de la Société de Géographie de Paris in I878. Ould-Braham, 'Émile Masqueray au Mzab', I4-I5.

I9 Even more broadly, of course, this process is part of the 'scientific' and artistic invention of the 'Orient' and the academic study of its cultures and languages. Edward Said famously critiqued this cumulative representation of the 'Orient' in his Orientalism (1978).

20 A. Hannoum, 'Colonialism and knowledge in Algeria: the archives of the Arab Bureau', History and Anthropology, I2:4 (2001), 343-79.

2 I B. Cohn, Colonialism and Its Forms of Knowledge: the British in India (Princeton, 2006), 4-5.

22 Ibid. 5 .

23 G. Trumbull IV, An Empire of Facts Colonial Power, Cultural Knowledge, and Islam in Algeria, I870-I9I4 (Cambridge, 2009), 8. Trumbull borrowed the notion of an 'ethnographic state' from another work on British colonialism in India: N. Dirks, Castes of Mind: Colonialism and the Making of Modern India (Princeton, 2OII).

24 Trumbull, An Empire of Facts, 9, emphasis added. 
Ethnography and history also worked hand in hand with colonial administration in neighboring Tunisia and Morocco, where the French established protectorates in I88I and I9I2, respectively. Although the French did not attempt to apply the same model of settler colonialism in these two regions as they did in Algeria, the production of knowledge about the history and cultures of their peoples followed similar patterns of fact-gathering established in that French 'colonial laboratory par excellence'. ${ }^{25}$ This was especially the case with French colonial historiography, which maintained an interest in premodern Arabic chronicles and histories. ${ }^{26}$ In describing French historiography in Morocco after I9I 2, for example, Mohamed El Mansour wrote that it

clearly reflected a specific ideological orientation. Its purpose was to justify French colonial designs in the region ... This was made clear by French officials who, by creating 'academic' institutions such as the Institut des Hautes Etudes Marocaines, wanted above all to better know 'l'âme marocaine' (the Moroccan soul) as a first step toward the installation of a Western order in place of the sterile Islamic one. ${ }^{27}$

Mansour added that as in Algeria, the interest of colonial academics and officials in Morocco extended to other domains such as archeology and ethnography. Edmund Burke III has recently offered a detailed study of the latter, demonstrating the ways in which the category of 'Moroccan Islam' was carefully constructed by ethnographers in the first decade and a half of the twentieth century. ${ }^{28}$

Like the work of earlier French ethnographers and the Arab Bureau in Algeria and later French and Italian historians in Morocco and Libya, Masqueray's journey to the Mzab in search of manuscripts was an exercise in the production of 'useful' knowledge, financed by a government that had a vested interest in gathering information about peoples under its control. ${ }^{29}$ Alongside the government, numerous 'colonial societies' and organizations in

25 A. Hannoum, 'De l'historiographie coloniale à l'historicisme national ou Comment le Maghreb fut inventé', Hespéris-Tamuda, 48 (2013), 6I.

26 This same interest in chronicles extended to French ambitions in western Africa after the occupation of the Western Sudan (especially the city of Timbuktu), where manuscripts of texts like the Tärikh al-südān and the Tärīkh al-fattāsh were collected, edited, and published in Arabic and French translation. On these texts, see al-Sa'dī 'Abd al-Raḥmān ibn 'Abd Allāh, Tarikh-es-Soudan par Abderrahman ben Abdallah, trans. O. Houdas (I 898); Maḥmūd Kutī ibn Mutawakkil Kutī Timbuktī, Tarikh el-fettach: fi akbbâr el-bouldân oua-l-djouyoûch oua-akâbir en-nâs: ou, Chronique du chercheur, pour servir à l'histoire des villes, des armées et des principaux personnages du Tekrour, trans. O. Houdas and M. Delafosse (Paris, I964). Both texts have more recently been studied and translated: 'Abd al-Rahmān ibn 'Abd Allāh Sa'dī and J. Hunwick, Timbuktu and the Songhay Empire: Al-Sa'di's Ta'rīkh Al-Südān down to I6I3, and Other Contemporary Documents (Leiden, 2003); Mahmūd Kutī ibn Mutawakkil Kutī Timbuktī, Ta'rīkh Al Fattāsh = The Timbuktu Chronicles, I493-I599: English Translation of the Original Works in Arabic by Al Haji Mahmud Kati, trans. C. Wise and Hala Abu Taleb (Trenton, 20II).

27 M. El Mansour, 'Moroccan historiography since independence', in M. Le Gall and K. Perkins (eds.), The Maghrib in Question: Essays in History \& Historiography (Austin, I997), I I I.

28 E. Burke III, The Ethnographic State: France and the Invention of Moroccan Islam (Berkeley, 20I4).

29 A similar situation proved true for the study of Ibāệ̀ communities in Libya under Italian colonization (I9I I47). Indeed, knowledge production on Libyans began only after the Italo-Turkish war (I9I I-I 2). According to A. Baldinetti, 'the Italian occupation of Libya had been planned without any preliminary cultural knowledge of the territories'. See her 'Italian colonial rule and Muslim elites in Libya: a relationship of antagonism and collaboration', in M. Hatina (ed.), Guardians of Faith in Modern Times: 'ulama' in the Middle East (Leiden, 2009), 9I. From that point onward, however, the situation changed. Interest in Ibadi 
Algeria financed the work of ethnographers and linguists like Masqueray. ${ }^{30}$ As Ould-Braham has demonstrated, Masqueray's correspondence with government officials constantly reiterated the importance of his work and the need for it to be financed. Masqueray's translation of the Kitāb al-sìra was part of a much larger series of studies he carried out with state funding. As Patricia Lorcin wrote, the 'academic perspective' that Masqueray brought to his other work on Berber villages in the Aurès and Mzab belongs to the broader context of the colonial state's goal of 'shed[ding] light on the institutional origins of Western civilization'. ${ }^{3 \mathrm{I}}$

Indeed, as both Lorcin and Trumbull demonstrate, academics worked in tandem with colonial administrators to produce similar kinds of useful knowledge. For example, writing just after the occupation of the Mzab valley in I882, French colonial administrator and military interpreter Adolphe Motylinski published an annotated list of Ibadi manuscripts that he introduced by noting his debt to Masqueray's translation of the Kitāb al-sìra. In addition, he specifically pointed out the link between the recent military occupation and the ability of the French to gather more information:

The Chronique d'Abou Zakaria, published in 1878 by M. Masqueray, drew attention to the books of the Beni Mzab. In the erudite notes appended to his translation, M. Masqueray had already pointed to other works of biography and jurisprudence. The annexation of the Mzab and the permanent occupation of the post of Ghardaia allowed for a continuation of bibliographic research so well begun [by Masqueray]. ${ }^{32}$

But Masqueray's translation of the Kitāb al-sìra came at the end of the period of the ethnographic state. In I87I, the colonial rule of Algeria changed from a military to civilian administration. Knowledge produced about Algeria and its peoples changed with it, moving toward what Abdelmajid Hannoum has called the 'historiographic state'. For Hannoum, the change to civilian administration in Algeria was accompanied by a shift in interest to the accumulation of historical data and the production of historiography that justified the colonial project. ${ }^{33}$ This took the form of societies and publications like Masqueray's Chronique d'Abou Zakaria, which uses a medieval text as a centerpiece of a study prefaced by an extended introduction on the importance of understanding a people's history and culture to rule them. For example, in discussing the stories of medieval texts of the Ibadis, Masqueray wrote:

communities also extended to medieval texts resulting from colonization, such as Italian Orientalist Roberto Rubinacci's studies of Ibādī manuscripts seized from the Ottoman mutasarrif in the town of Yefren in I9I3 and brought to Naples. See R. Rubinacci, 'Notizia di alcuni manoscritti ibāditi esistenti presso l'Istituto Universitario Orientale di Napoli', Annali dell Instituto Universitario Orientale di Napoli, 3 (I949), 43 I-8.

30 Trumbull, An Empire of Facts, 43.

3 I P. Lorcin, Imperial Identities: Stereotyping, Prejudice, and Race in Colonial Algeria (Lincoln, NE, 2014), I8990.

32 A. Motylinski, 'Bibliographie du Mzab: les livres de la secte Abadhite', Bulletin de Correspondance Africaine, 3 (I 885), 5. Motylinski himself later published his own edition of yet another medieval text on Ibadi history, the ninth-century history of the Ibadi Rustamid dynasty: Ibn al-Saghīr, Chronique d'Ibn Saghir sur les imams rostemides de Tahert, trans. A. Motylinski (Paris, I907).

33 A. Hannoum, 'The historiographic state: how Algeria once became French', History and Anthropology, 19:2 (2008), 9I-II4. 
These pious legends fill large volumes. They are neglected today and I know an interpreter [for the French military] who, having been asked to translate one of these books, responded that it contained nothing but silliness. This is, I think, to speak too lightly. In our opinion, to this 'silliness' are tied a thousand serious matters, decisions of religious jurisprudence, historical and geographic information, and diverse customs. Moreover, if we want to understand a people in order to govern them, we must take them as they are, excluding nothing. ${ }^{34}$

For Masqueray, the value of understanding the Ibadi past was inextricably linked with the usefulness of this knowledge in the present.

Although a clear example of the relationship between historiography of medieval texts and the production of useful knowledge in colonial northern Africa, Masqueray's Chronique is far from unique in this regard. For example, Abdelmajid Hannoum has demonstrated the tremendous impact of Baron de Slane's translation of fourteenthcentury historian Ibn Khaldun's (d. I406) famous Kitāb al-ibar under the title Histoire des Berbères in I $856 .{ }^{35}$ Indeed, it is fitting that the footnotes to Masqueray's translation are complemented throughout by reference to de Slane's. As Hannoum has argued, translations like those by Masqueray and de Slane effectively created new texts, rewritten in the idiom of French colonial discourse and made accessible to the great synthesizers of Maghrib history whose work shaped generations of historiographical conversations on the region. In other words, just as had been the case with ethnography in an earlier period, studies and translations of medieval texts like Masqueray's or de Slane's were as much political as academic enterprises that served the colonial government's interest, helping to create and to maintain 'French conceptions of Algerian identity.'36

The French did not produce colonial historiography on their own, however. Just as Trumbull noted regarding the informants and subjects for ethnographic studies in an earlier period, northern Africans themselves had a role in the formation of historiography on the medieval Maghrib in the late nineteenth and early twentieth centuries. The account Masqueray relates of his acquisition of Ibadi manuscripts in the Mzab demonstrates that translations and editions of medieval texts were often based upon manuscripts of very recent production, provided to researchers by local actors. The Kitāb al-sìra may have been an eleventh-century composition, but the manuscript upon which Masqueray produced his Chronique was the product of a student in the Mzab valley in the I870s who copied it for him. Moreover, the broader historical narrative offered in his introduction was presented to him by Shaykh Amuhummad Ațfayyish. In this way, Ibadis themselves

34 Masqueray, Chronique d'Abou Zakaria, I 5 I, fn. I.

35 A. Ibn Khaldūn, Histoire des Berbères et des dynasties musulmanes de l'Afrique Septentrionale, trans. W. de Slane (Algiers, I 852); A. Hannoum, 'Translation and the colonial imaginary: Ibn Khaldûn Orientalist', History and Theory, 42:I (2003), 6I-8I. Hannoum expanded on the theme of colonial-era historiography in his Violent Modernity: France in Algeria (Cambridge, MA, 20I0). His earlier monograph on the legend of the Kahina demonstrates explicitly how premodern history was used by French historians to rewrite the early history of Islam in support of colonial ideology. See his 'Colonial histories', in A. Hannoum, Colonial Histories, Post-Colonial Memories: The Legend of the Kabina, a North African Heroine (Portsmouth, 200I), 29-70.

36 Trumbull, An Empire of Facts, I2. 
had an active role in shaping French historiography and in controlling the texts to which researchers had access.

Other studies of Ibadi texts and history during the late nineteenth and early twentieth centuries follow similar patterns. For example, the collection of Ibadi manuscripts from the Mzab valley and other parts of northern Africa upon which Polish Orientalist Tadeauz Lewicki (I906-92) published dozens of studies on Ibadis includes manuscripts commissioned by Lewicki and his mentor, Zygmunt Smogorzewski ( I 884-I93 I) while in the Mzab valley. ${ }^{37}$ Although they had little power to determine what was later done with the information acquired from these texts, by attempting to control which texts were available to colonial-era researchers Ibadis played a role in shaping colonial historiography. ${ }^{38}$

One of the clearest indications of the long-term 'usefulness' and impact of Masqueray's translation of the Kitāb al-sirra is the number and variety of studies that referenced it. References to the Chronique appear not only in the specialized literature on Ibadi history by Tadeausz Lewicki, Adolphe Motylinksi, and others, but also in synthetic studies of Maghribi history from the twentieth century. These include popular titles that went through multiple editions like George Marçais's La Berbérie musulmane et l'orient au moyen âge, Charles Andres-Julien's Histoire de l'Afrique $d u$ Nord, and Jamil Abu-Nasr's A History of the Maghrib in the Islamic Period. ${ }^{39}$ References to the translation also appear in articles on Ibadi history in the widely-used first and second editions of the Encyclopedia of Islam as well as the French compendium of primary sources on northern and western Africa by J. M. Cuoq, Recueil des sources arabes concernant l'Afrique occidentale $d u$ VIIIe au XVIe siècle. ${ }^{40}$

37 Many of the manuscripts used by Z. Smogorzewski were, in fact, part of the collection of A. Motylinski that had been sold to the Parisian book dealer Paul Geuthner at the beginning of the twentieth century. On Smogorzewski and Lewicki, see K. Kościelniak, 'The contribution of Prof. Tadeusz Lewicki', 24I-55.

38 A recent article on the 'Agadez Chronicles' in what is today Niger has similarly argued that manuscript copies of those text provided to Europeans by local actors 'had been altered to promote the interests of local elites who circulated these sources'. See B. Rossi, 'The Agadez Chronicles and Y Tarichi: a reinterpretation', History in Africa, 43 (2016), 95-I40. Many thanks to the anonymous reviewer who brought this reference to my attention.

39 On Lewicki's work, see fn. 2. Motylinski references Masqueray's work in both his Bibliographie and his 1907 translation Chronique d'Ibn Saghir sur les imams rostemides de Tahert. Another classic work from the twentieth century on Ibadism that references Masqueray is P. Cuperly, Introduction à l'étude de l'ibādisme et de sa théologie (Alger: Office des publications universitaires, I984). See also G. Marçais, La Berbérie musulmane et l'Orient au moyen âge, Les grandes crises de l'histoire (Paris, I946); C. A. Julien, Histoire de l'Afrique du Nord: Tunisie, Algérie, Maroc (Paris, I93I); J. M. Abun-Nasr, A History of the Maghrib (Cambridge, I97I).

$40 \mathrm{~J}$. M. Cuoq, Recueil des sources arabes concernant l'Afrique occidentale du VIIIe au XVIe siècle (Bilad Al-Sudan) (Paris: CNRS, 1985). Similar Ibadi texts are extracted in the English equivalent to Cuoq's corpus: J. F. P. Hopkins and N. Levtzion, Corpus of Early Arabic Sources for West African History (Cambridge, 198I), 88-9I. Those extracts are translated from the French translations made by T. Lewicki, who also references Masqueray but elects to provide his own translations accompanied by the Arabic. For the section on the Kitāb al-sirra, see T. Lewicki, 'Quelques extrait inédits relatifs aux voyages des commerçants et des missionnaires ibadites nord-africains au pays du Soudan occidental et central au moyen âge', Folia Orientalia, II (1960), $2-7$. 


\section{LETOURNEAU, IDRIS, AND THE UNIVERSITY OF ALGIERS}

Although Masqueray's translation of the Kitā b al-sìra was widely used in studies from the time of its publication through the mid-twentieth century, French and francophone historians of the Maghrib regularly noted its poor quality and incompleteness. Perhaps the most prolific writer on Ibadi communities in medieval northern Africa, Tadeusz Lewicki, referred to Masqueray's translation as 'very mediocre and incomplete'. ${ }^{4 \mathrm{I}}$ In the I950s a group of historians and philologists at the University of Algiers responded by making use of several manuscript copies of the Kitāb al-sira to prepare a revised edition. The new translation of the text appeared in four installments from $1960-2$ in Revue Africaine under the editorship of French Orientalists Roger LeTourneau (1907-7I) and Hady Roger Idris (1912-78), both of whom taught at the University of Algiers in the I950s. ${ }^{42}$ The introduction to the first part of the translation (under the slightly modified title 'La Chronique' d'Abû Zakariyyâ') explains the circumstances of its publication:

The Chronique d'Abû Zakariyyâ' was unknown other than the partial translation given by Emile Masqueray in $1878 \ldots$ Since 1930 , new manuscripts - some fragmentary, others complete - were discovered. A team of Arabists and historians has taken up the task of publishing the Arabic text and its annotated translation. The Revue Africaine is delighted to be able to offer in this volume the first part of this Chronique, the translation of which is due to Professor Roger Le Tourneau based on the text established by Mr. Charles Dalet, honorary professor of the Lycée Bugeaud d'Alger. ${ }^{43}$

In the preface to the same volume of Revue Africaine, the notes from the General Assembly of the Société Historique Algérienne on future publications clarify that the text was to be published as the 'translation of Messrs. Le Tourneau and Idris based on the Arabic text established by Messrs. E. Dalet [sic] and H[enri] Pérès'. ${ }^{44}$ As early as 1958, this 'team of Arabists and historians' had planned a publication of the Arabic text to accompany the translation but political events in Algeria led to its delay and eventual abandonment. In light of the deteriorating political situation, LeTourneau had decided to leave Algeria in 1957 and take up a post at the University of Aix-en-Provence in France. ${ }^{45}$ After defending his thesis, his colleague Hady Idris stayed behind in Algiers until his own departure in I96I for Bordeaux. ${ }^{46}$ Thanks to LeTourneau's correspondence with Idris and others held in the Archives nationales

$4 \mathrm{I}$ T. Lewicki, Les historiens, biographes et traditionnistes ibādites-wahbites de l'Afrique du Nord du Vllle au XVle siècle (Krakow, I962), 3 .

42 L. Golvin, 'Roger Le Tourneau, l'homme, le savant: travaux de Roger Le Tourneau', Revue de l'Occident musulman et de la Méditerranée, Io (197I), 9-I 8; D. Sourdel, 'Hady-Roger Idris (I9I2-I978)', Revue des études Islamiques, 2:46 (I978), I 55-6I.

43 Letourneau, 'La Chronique', 99.

44 Ibid. 8.

45 On the relationship between Roger LeTourneau's scholarship as a historian and his politics, see S. Saul, 'Roger Le Tourneau: un historien de l'Afrique du Nord face à la décolonisation', Outre-mers, 93:350-I (2006), 33565.

46 Sourdel, 'Hady-Roger', I 56 . The thesis was later published as H. Idris, La Berbérie Orientale sous les Zirides, 2 vols. (Paris, I962). 
d'outre-mer (ANOM) in Aix-en-Provence, the history of the publication of the second translation of the Kitāb al-sìra survives. ${ }^{47}$

Like the introduction to the first part of the Chronique, the notes and letters of LeTourneau's private archive suggest that he intended to publish the Arabic text along with a translation. As early as I7 April I95 $8,{ }^{48}$ Marius Canard from the University of Algiers wrote to LeTourneau to tell him about a young Tunisian scholar, Farhat Dachraoui, who had recently obtained a microfilm of the Kitāb al-sìra from Lewicki. Dachraoui was hoping to see the University of Algiers manuscript for comparison and eventual publication. ${ }^{49}$ Canard wanted to alert LeTourneau ahead of time because the latter was planning to publish the text himself. Foreshadowing events to come, Canard ended his letter with a remark on recent 'provocations' by the Algerian nationalist movement, the Front de Libération Nationale (FLN). ${ }^{\circ}$

Later correspondence confirms these plans for an Arabic publication. In a letter dated I 3 December 1958, retired lycée professor Charles Dalet wrote from Algiers to LeTourneau in Aix-en-Provence, requesting that the latter complete his project to publish the Chronique

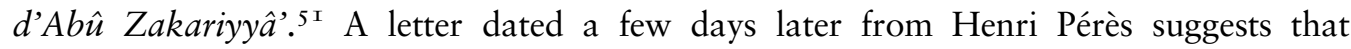
LeTourneau had already been working with Dalet on the project and had been responsible for the translation. Pérès requested that LeTourneau send the first half of the Arabic text for publication with annotations. ${ }^{52}$ The archival folder containing the correspondence also includes a handwritten copy of the Kitāb al-sìra in Arabic, with notations for printing and corresponding folios from the manuscript exemplar. ${ }^{53}$

Original plans to publish the Arabic text, probably in the Bulletin Arabe-Français, did not come to fruition. A letter from the University of Algiers library dated 9 May I959 thanked LeTourneau for returning three items, including two manuscripts for Pérès and one additional photograph of a manuscript belonging to the library. ${ }^{54}$ LeTourneau had apparently used these manuscripts to complete his translation. In a letter dated I 8 May, Pérès suggested publishing the translation in Revue Africaine, with no further mention of the Arabic text. ${ }^{55}$

Soon thereafter, LeTourneau departed Provence for, among other places, Madagascar and then Princeton University, where he took up a visiting professorship. He did not intend to finish either the Arabic text or the translation of the second part of the Kitāb al-sìra. ${ }^{56}$ Instead, Pérès suggested that LeTourneau's younger colleague and friend in Tunisia, Hady

47 The 'Fonds Le Tourneau' is held at the Archives nationales d'outre mer (ANOM). I have used the reference to this archive's documents as it appears in other publications: Centre des archives d'outre mer (CAOM), 7/ $\mathrm{APOM} / \mathrm{I}-29$.

$48 \mathrm{CAOM} 7 / \mathrm{APOM} /$ Io, letter from Canard to LeTourneau, I7 Apr. I958.

49 Darchaoui later used the Kitāb al-sìra to write his Le califat fatimide au Maghreb (296-365H./909-975JC.): histoire politique et institutions (Tunis, I98I). On Lewicki, see Kościelniak, 'The contribution of Prof. Tadeusz Lewicki'.

$50 \mathrm{CAOM} 7 / \mathrm{APOM} /$ Io, letter from Canard to LeTourneau, I7 Apr. I958.

5 I CAOM 7/APOM/I 2, letter from Dalet to LeTourneau, I3 Dec. I958.

$52 \mathrm{CAOM}$ 7/APOM/I 2 , letter from Pérès to LeTournea, I 8 Dec. 1958.

$53 \mathrm{CAOM}$ 7/APOM/ I 2, 'Chronique d'Abou Zakariyyâ', n.d.

$54 \mathrm{CAOM} 7 / \mathrm{APOM} / \mathrm{s}$, letter from University of Algiers Library to LeTourneau, 9 May 1959.

$55 \mathrm{CAOM}$ 7/APOM/I2, letter from Pérès to LeTourneau, I 8 May I959.

56 Saul, 'Roger Le Tourneau', 338. 
Roger Idris, complete the second half. ${ }^{57}$ Idris had exchanged letters with LeTourneau in the past. ${ }^{58}$ Not until January I959, however, did Idris first mention the translation project. ${ }^{59}$ In a letter from Gammart (Tunisia) Idris asked LeTourneau how the Arabic text had been established. He doubted the accuracy of some of the orthography and suggested, as he would do in latter letters, using a manuscript copy of thirteenth-century Ibadi historian Abū l-'Abbās Aḥmad al-Darjīnī's Kitāb al-țabaqāt held at the University of Algiers Library and the Egyptian lithograph of late fifteenth-century historian Abū l-'Abbās al-Shammākhī's Kitāb al-siyar to corroborate the Arabic text. ${ }^{60}$

The first half of the translation, attributed to LeTourneau, appeared in Revue Africaine in $1960 .{ }^{61}$ During that same period, Idris began working on the second half of the translation in Algiers. In a letter dated ro May, Idris informed LeTourneau that he had established the text by comparing it with additional manuscripts of Abū Zakarīyā' and al-Darjīn̄ 1 at the University of Algiers. ${ }^{62}$ The manuscripts upon which they based the new translation may have been among those donated to the university by French colonial military interpreter Adolphe Motylinski in the late I $880 \mathrm{os},{ }^{63}$ although without a catalog of the university's manuscript holdings from that time it is impossible to know for certain. ${ }^{64}$ Ultimately, the two-part translation of the second half of the Kitāb al-sìra based on these manuscripts appeared in the I96I and I962 volumes of Revue Africaine, this time attributed to Idris. ${ }^{65}$

Even at this late date, however, efforts to publish an Arabic version of the texts had not yet been abandoned entirely. In a letter dated Io December I96I, Henri Pérès requested that LeTourneau send along an introduction to the 'the text' by January to follow his own preface about the manuscript copies of 'La Chronique'. Meanwhile, however, the political climate was changing in Algeria. Tellingly, Pérès added that he was in a hurry to finish with the Arabic text and be done with it-especially since he was not sure he would be returning to Algiers in light of recent political changes and the escalation of violence. ${ }^{66}$ Earlier that year LeTourneau had received a letter from the Swiss archeologist and art historian Marguerite van Berchem, who wrote to say how much she looked forward to his new translation of the Chronique. Van Berchem, preparing her own study of the medieval Ibadi city of Sedrata discussed in the book, added that LeTourneau's former colleague in Algiers Marius Canard had promised to share the text with her 'but with these events in Algeria, I am afraid he will have had other preoccupations! ${ }^{67}$

57 Ibid.

$58 \mathrm{CAOM}$ 7/APOM/Io, letters from Idris to LeTourneau: I8 Nov. I957; 20 Nov. I958; 20 Jan. I959.

$59 \mathrm{CAOM} 7 / \mathrm{APOM} / \mathrm{s}$, letter from Idris to LeTourneau, 26 Jan. 1959.

60 Both of these later works quoted extensively from the Kitāb al-sir $r a$ and have appeared in print editions:

A. al-Darjīn̄̄, Kitāb țabaqāt al-mashā'ikh bi-l-maghrib., ed. I. Tallay, 2 vols. (Constantine, I974); A. al-Shammākhī, Kitāb al-Š̀yar, ed. M. Hasan, 3 vols. (Beirut, 2009).

6I Letourneau, 'La Chronique'.

$62 \mathrm{CAOM} / 7 \mathrm{APOM} / \mathrm{so}$, letter from Idris to LeTourneau, ıo May 1960.

63 Z. Smogorzewski, 'Essai de bio-bibliographie ibadite-wahbite, avant-propos', Rocznik Orientalistyczny, 5 (I927), 48.

64 Motylinski also noted that his own manuscript copy was made from the exemplar used to produce Masqueray’s copy, see Motylinski, 'Bibliographie du Mzab: les livres de la secte Abadhite', 26.

65 Idris, 'La Chronique ... deuxième partie'; 'La Chronique ... deuxième partie (suite)'.

$66 \mathrm{CAOM} 7 / \mathrm{APOM} / \mathrm{s} 2$, letter from Pérès to LeTourneau, ıo Dec. I96I. 
The conclusion of the Évian accords in March 1962 brought an end to eight years of bloody war between France and the FLN, setting the stage for independence later that year. This sign of hope for Algeria's future was followed by a tragedy tied directly to history of the Kitāb al-sìra. On 7 June, the militant, pro-French Algeria group 'L'organisation Armée secrète' (OAS) set fire to the University of Algiers library and the ensuing flames devoured almost all the manuscript holdings. ${ }^{68}$ Among the many works lost were the manuscript copies of several Ibadi texts in Arabic, including the Kitāb al-sìra. The only surviving traces of these and the hundreds of other lost manuscripts were the French translation of the Kitāb al-sìra in Revue Africaine and the new manuscript copy of the Arabic text in LeTourneau's private archive dating to the I950s. ${ }^{69}$

Like Masqueray's Chronique d'Abou Zakaria, this new translation of the Kitāb al-sìra and the story of its publication belong to the history of French colonialism in northern Africa. But unlike Masqueray's text, which represented a transition from an 'ethnographic' to a 'historiographic' state in the late nineteenth century, LeTourneau and Idris's translation marked the end of the French colonial enterprise in the region in the mid-twentieth century. Over the I 30 years of French colonization in Algeria, historiography changed with the political circumstances that helped shape its production. The University of Algiers in I960 represented a very different kind of institution for the production of knowledge than had the Arab Bureau in the nineteenth century.

The manuscripts upon which this new translation of the Kitāb al-sìra was based did not require any misadventures to the Mzab valley or any clever 'ruses' by ethnographers. That is, the production of colonial knowledge was a civilian rather than a military-led effort by the mid-twentieth century: the site of production for this new translation was the city of Algiers and the library of the University of Algiers. On the surface, this serialized translation was an exercise in philology seemingly divorced from the late colonial context that produced it. Only hints in the correspondence behind its publication suggest that this new translation was prepared and published during such a tumultuous moment in Algerian history. The destruction of the library housing the manuscripts by the OAS serves as a jolting reminder of material entanglements of the publication history of the Kitāb al-sirra and the reality of colonialism in Algeria.

In addition to the site of its production, the medium of its publication also connects this new translation of the Kitāb al-sira to the late colonial context of the twentieth century that produced it. Revue Africaine was one of several publications by societies and institutions that since the late nineteenth century served as media for the production and dissemination of knowledge about northern Africa. Established in 1856 by and for the Société Historique Algérienne, Revue Africaine was designed-as the introduction to its first volume

67 '[M]ais avec ces événements d'Algérie je peur [sic] qu'il aura eu bien d'autres préoccupations!' CAOM 7 / $\mathrm{APOM} / \mathrm{s} 2$, letter from Van Bercham to LeTourneau, I Jan. I96r.

68 See A. Abdallah, 'III. L'incendie', in 'Histoire de la Bibliothèque Universitaire d'Alger et de sa reconstitution après l'incendie du 7 juin I962', Université d'Alger Bibliothèque Universitaire, (http://bu.univ-alger.dz/ Reconstitution_de_la_B.U.pdf) accessed 22 Dec. 20I4. The office of the library's director today contains a glass display case with some of the charred remains of the books lost in the fire.

69 This includes a full copy of the Kitāb al-sìra and a partial copy of al-Darjīnī's Kitāb țabaqāt: CAOM 7/APOM/ I2. 
announced - as 'an organ dedicated to the publication of [the society's] works' ${ }^{70}$ And for a century, Revue Africaine served faithfully as the mouthpiece for the systematic production of knowledge about French colonial Algeria and northern Africa.

This remained the case all the way up until the appearance of its final volume in I962, as the French prepared their final exit from Algeria. At Io am on 28 January I960, the General Assembly of the Société was held at Faculté des Lettres et Sciences Humaines in Algiers. ${ }^{7 \mathrm{I}}$ Its proceedings give virtually no indication of the tumult occurring throughout the country (or just outside on the streets of Algiers) and certainly no sign that the end was coming. The president's address began with the obituaries and tributes to recently deceased members of the Société. A telling sign of events to come, however, was the lamented departure of two individuals - not to the afterlife, but to the metropole. Former Société president George Marçais and Professor Marius Canard, 'two of our distinguished university confreres ... have left us definitively to enjoy a well-earned sojourn in the metropole' ${ }^{72}$ The departure of Canard, portended in the correspondence regarding the publication of the translation of the Kitāb al-sira, followed LeTourneau's as the faculty of the University of Algiers gradually abandoned ship. LeTourneau went to Aix, Canard to Paris, and Idris to Bordeaux.

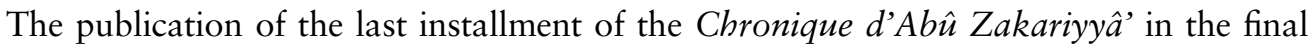
volume of Revue Africaine had brought the history of the translation of the Kitāb al-sira full circle from its first translation by Masqueray at the close of the nineteenth century. That first translation marked the beginning of the French domination of the Sahara, the end of the ethnographic state, and the beginnings of civilian rule in Algeria. The content, editors, site of production, and medium of publication for this second translation in Revue Africaine - collectively symbolizing the power and longevity of the production of colonial knowledge about northern Africa - marked the final moment of the historiographic state in Algeria in 1962.

\section{THE POST-INDEPENDENCE KITĀB AL-SīRA}

Nearly a century after its first publication in French translation as the Chronique d'Abou Zakaria, an Arabic edition of Kitāb al-sìra made its way to the press in I979. If previous publications of the text in translation mirror the colonial context out of which they emerged, the subsequent editions in Arabic in 1979 and 1985 reflect the legacy of colonialism in northern Africa and the efforts of post-independence historiography to decolonize the history of the region and recast it in a nationalist framework. ${ }^{73}$ More specific to

70 A. Berbrugger, 'Introduction', Revue Africaine, V.I ( 1856 ), 3. This introduction also lays out a short history of the production of knowledge on Algeria from the occupation of Algiers in I 830 to the mid-nineteenth century.

7I The proceedings of the meeting appear at the beginning of the final issue of Revue Africaine, under the title of 'Assemblée Générale du 28 Janvier I962' (presumably the organization's very last general assembly): Revue Africaine, 106 (I962), 5-9.

72 Ibid. 7 .

73 These efforts are represented by classic works of post-independence Maghribi history like M. Sahli, Décoloniser l'histoire: introduction à l'histoire du Maghreb (Paris, I965) and A. Laroui, L'histoire du Maghreb (Paris, 1975), translated as The History of the Maghrib: An Interpretive Essay (Princeton, I977); J. Wansbrough, 'The decolonization of North African history', The Journal of African History, 9:4 (I968), $643-50$. For an overview of the literature and the historiographical conversation over the decolonization of 
Algeria, the post-independence publications of the Kitāb al-sīra offer further examples in support of James McDougall's argument that historiography in an independent Algeria reshaped the region's past with new framings of historical narratives that responded to and replaced those written in the colonial era. ${ }^{74}$

The first printed edition of the Kitāb al-sìra, appearing under the title Kitāb siyar al-a'imma wa-akbbāribim, included only the first half of the text. It was edited by Algerian historian Ismā'îl al- 'Arabī, who relied on manuscript copies he obtained in the Mzab valley in Algeria. ${ }^{75}$ In his introduction, al- Arabī reviewed the previous editions of the text that had appeared in French translation. Regarding Masqueray's edition, he expressed dissatisfaction with both the incompleteness of the manuscript and the translator's lack of what he perceived as the proper level of competency in Arabic:

[A]t the time in which [Masqueray undertook his translation], his level of Arabic did not exceed that of a French teacher in a secondary school in this language during the colonial period. In this context, we observe that the method followed by the translator was one in which he simply ignored the sentence[s] in which he found difficulty reading one of the words. ${ }^{76}$

Without comparing Masqueray's translation with the original manuscript copy with which he was working, it is not possible to argue for or against al-'Arabī's judgment of his translation. But this technical critique, which as al-'Arabī pointed out had already been made earlier by European Orientalists including George Marçais and Tadeusz Lewicki, preceded a much harsher critique of Masqueray and the French colonial project his work represented. In addition to what he perceived as the uselessness of most of Masqueray's footnotes (which together amounted to a much longer subtext than the Chronique itself), al-'Arabī wrote that the tone and purpose of the text spoke to the violence it did to Algeria:

Worse than all of the preceding is the blatant colonial spirit (al-rūt al-isti māriyya al-fijia) that blackens the footnotes of the translator and his introduction, the likes of which we only find in the first generation of colonizers .... The translator strikes us with this inclination, bringing it to the fore at both appropriate and inappropriate times, especially in his use of terms like: 'our possessions', 'our Algeria', 'our Shāwiyya', and 'our Mzab'. All of this is repeated in the introduction and the footnotes with the pride and honor with which a feudal lord speaks of his lands and slaves. In the mind of the translator, the entire process [of translation] is not limited to [the] transmission of information and the presentation of a service to researchers and scholars. Rather, [the translation] aims to provide a background in which the colonizers can understand the 'mentality of the people whom they rule: for if we desire to understand a people so that we may rule them, it is necessary that we take them as they are. ${ }^{77}$

Likewise, al-'Arabī criticized the later translation in Revue Africaine by LeTourneau and Idris, noting not only various errors and the oddness of yet another French translation

history in the Maghrib, see K. Perkins, 'Recent historiography of the colonial period in North Africa: the "Copernican Revolution" and beyond', in Le Gall and Perkins (eds.), The Maghrib in Question, I2 I-35.

74 J. McDougall, History and the Culture of Nationalism in Algeria (Cambridge, 2006).

75 al-Warjalān̄̄, Kitāb siyar al-a'imma, 26-7.

76 Ibid. 29.

77 Ibid. 30. 
appearing instead of an Arabic printed edition, but also that the unnamed team of Arabists at the University of Algiers neglected to provide any information on the manuscript(s) used for their translation. ${ }^{78}$

In his criticisms of these colonial-era translations of the text, al- 'Arabī represents an early polemical trend in post-independence Maghribi historiography advocating for the decolonization of Islamic history in northern Africa that initially seemed intent on replacing it with a nationalist ideological framework. ${ }^{79}$ As Houari Touati has argued, post-independence historiography in Algeria 'operated as the inverse of colonial historiography'. ${ }^{\circ} \mathrm{A}$ period of nationalist historiography that situated even ancient Roman to medieval periods into a nationalist framework provided a kind of counterbalance to a long-standing colonial tradition of history writing. Many of the same periods and personages that served as the focus of colonial historiography were repurposed in the post-independence period to produce very different readings of the past, more in line with - and 'useful' to - the nationalist visions of Morocco, Algeria, Tunisia, or Libya. ${ }^{8 \mathrm{I}}$

The publication of the first full Arabic edition of the Kitāb al-sìra in I985 likewise emerged out of the region's colonial past, although under very different circumstances. While studying in Paris in 1976, Tunisian historian 'Abd al-Raḥmān Ayyūb received a phone call from a friend about a collection of manuscripts belonging to the late Jean-Auguste Bossoutrot (d. I937). ${ }^{82}$ Bossoutrot, who had worked with the French military in southern Algeria and Tunisia, had himself been working on a translation of the text based on a manuscript in his possession although he never published it. ${ }^{8}$ Using this copy along with another from the Dār al-Kutub library in Cairo, Egypt, Ayyūb edited a new Arabic edition under the slightly modified title Kitāb al-sīra wa-akhbār al-a 'imma. ${ }^{84}$

Ayyūb was keenly aware of the political nature of this work and its publication history. While discussing previous editions of the Kitāb al-sìra, he continually raised the question as to why this work had appeared in French three times before appearing in Arabic (his

78 Ibid. 3 I.

79 On these two larger historiographical trends, see the essays in Le Gall and Perkins (eds.), The Maghrib in Question. See also the introductions to S. Dulucq, Écrire l'histoire de l'Afrique à l'époque coloniale, XIXeXXe siècles (Paris, 2009) and P. Buresi and M. Ghouirgate, Histoire du Maghreb médiéval: (XIe-XVe siècle) (Paris, 20I4); Cf. J. E. Wansbrough, 'The decolonization of north African history', 643-50.

$80 \mathrm{H}$. Touati, 'Algerian historiography in the nineteenth and early twentieth centuries: from chronicle to history', in Le Gall and Perkins (eds.), The Maghrib in Question, 93.

8 I For Moroccan examples, see 'Postindependence historiography' and 'Nationalist history' in M. El Mansour, 'Moroccan historiography', in Le Gall and Perkins (eds.), The Maghrib in Question, I I2-I6. For Libya, see M. Le Gall, 'Forging a nation-state: some issues in the historiography of modern Libya', in Le Gall and Perkins (eds.), The Maghrib in Question, 95-108. A. Hannoum follows the famous legend of the Kahina into the post-independence period: 'Post-colonial memories', in Hannoum, Colonial Histories, Post-Colonial Memories, I I I-60, esp. 'The legend in post-colonial Arab historiography', I I9-3 I.

82 Ayyūb first described these documents in a short article in French: A. Ayoub, 'Deux pièces d'archive retrouvées parmi les documents de feu Jean Auguste Bossoutrot', Revue d'histoire Maghrébine, 2I-2 (I98I), 93-4. His full explanation came later with his publication of the Kitāb al-sìra (al-Warjalānī, Kitāa al-sìra, 7). Despite Ayyūb's note that the manuscripts were then sold to the 'Centre de littérature et de linguistique arabes. E.R. A. 585 Sorbonne Nouvelle (Paris II)', my visit to the CNRS library housing Arabic materials yielded no trace of these manuscripts. I wish to thank Moez Dridi for his help in the search for these texts in March 2015.

83 al-Warjalānī, Kitāb al-sīra, IO-I2.

84 Dar al-Kutub MS 9030 Ḥā', A. al-Warjalānī, Kitāb al-sīra, I 5 Jumādā al-ūlā I302/2 Mar. I885. 
bibliography suggests Ayyūb was unaware of al- Arabī's earlier edition), adding sardonically, 'It was as if Abū Zakarīyā' wrote the Kitāb al-sìra only so that it might be translated into French. ${ }^{, 85}$ Like al- 'Arabī's, Ayyūb's edition emerged from colonial legacy of the French in the post-independence period. His chance encounter with a colonial official's private archive had led him - a Tunisian historian educated and living in Paris - to undertake the edition in the first place. In many ways, this speaks to the decidedly different reality of French colonialism in Tunisia and the different body of historiographical material that was produced there. Rather than erase or conquer the production of knowledge on premodern history, as had been the case in Algeria, the French colonial project in Tunisia had produced a generation of historians who participated in the production of knowledge about the region's past. ${ }^{86}$ While Ayyūb's edition of the Kitāb al-sīra made sarcastic reference to the French translations that preceded his Arabic edition, there was comparatively little sense of polemical tone of Maghribi history and colonialism that had characterized al-'Arabī's edition.

Finally, just as the Chronique d'Abou Zakaria was not the only 'useful' translation of a medieval work edited and published in the colonial period, the Kitāb al-sìra was not the only medieval Ibadi text published and recast in a nationalist framework in the postindependence period. For example, in his introduction to the I974 edition of the thirteenth-century work the Kitāb al-țabaqāt, Algerian historian Ibrāhīm Tallāy wrote:

What pushed me to carry out this illuminating task and encouraged me in it was none other than what we in our Maghrib need in the way of reviving our heritage and the most prominent of our historical personalities and linking our illuminated present to our glorious past - and this so that we might build our renaissance (nahdatana $\bar{a}$ ) upon both the pillars of authenticity and openness, ... that cultural renaissance which Algeria and the rest of the countries of the Arab Maghrib are living. ${ }^{87}$

Like the Kitāb al-sirra, the publication of this medieval text contributed to the construction of a nationalist (in this case both Algerian and pan-Maghribi) historical narrative. It offers a useful addition to an authentic past, one (re)built in the new context of an independent Algeria.

\section{CONCLUSION}

I have focused here on the publication history of the Kitāb al-sìra in the late nineteenth and early twentieth centuries with the aim of demonstrating that it constitutes as much a part of the history of colonialism in northern Africa as that of the medieval period out of which it emerged. In following the history of its publication, I have argued that the Kitāb al-sìra and its various forms and translations did not appear in print and become available to

85 'Ka'anna kitāb al-sīra lam yaḍa 'hu Abū Zakarīyā Yahyā b. Abī Bakr al-Wārjalānī illā li-'an yutarjam li-l-lugha al-faransiyya' - (al-Warjalānī, Kitāb al-sīra, I I).

86 Indeed, this generation of historians included one of the editors of the second French translation of the Kitāb al-sira, Hady-Roger Idris, who was himself from a Franco-Tunisian family. On some of the resulting differences between the post-independence historiography in Algeria and Tunisia, see Perkins, 'Recent historiography of the colonial period in North Africa', in Le Gall and Perkins (eds.), The Maghrib in Question, I 24-6.

87 Aḥmad ibn Sa‘̄id al-Darjīn̄i, Kitāb țabaqāt al-mashā’ikh bi-l-Maghrib., ed. I. Ṭallay (Constantine, I974), [no page number]. 
historians for academic purposes alone. Rather, each stage in this story is connected to the history of colonialism in Algeria and its legacy in the historiography of northern Africa.

The first two publications of the Kitāb al-sìra in French translation as the Chronique

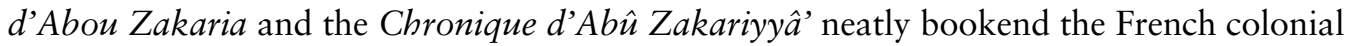
project in southern Algeria. Emile Masqueray's printed edition appeared in 1878 , framed with an introduction and footnotes that reflect French colonial aspirations in the Mzab valley and the Sahara. These aspirations would be actualized with the region's occupation only five years later, giving rise to a large literature by francophone Orientalists on the Mzab valley and its Ibadi inhabitants. Masqueray's single manuscript copy of the Kitāb al-sira, acquired through clandestine means despite the initial wishes of the Ibadi scholars of the Mzab and translated into French, became a window for academics and colonial officials alike into the history and culture of the Mzab. Straddling the eras of the ethnographic and historiographic states, the Chronique exemplified the production of 'useful' colonial knowledge at the end of the nineteenth century.

By contrast, the second, serialized translation of the Kitāb al-sìra in Revue Africaine from I960 to I962 marked the end of French colonial power in both the Mzab and nor-

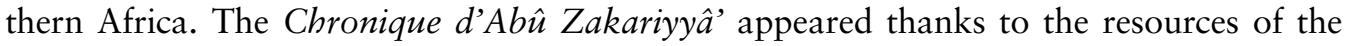
University of Algiers, including its rich manuscript collection at the disposal of French historians LeTourneau and Idris. Nevertheless, its publication coincided with the final days of French occupation. The publication of this second translation mirrors the coming change to the political landscape through both the flight of its editors to France as the country moved toward independence and the tragic loss of the manuscript materials upon which it was based in a fire set by the OAS - an organization determined not to see the end of l'Algérie française. Moreover, the surviving correspondence relating to its publication also suggests that the political climate of late I950s Algeria prevented the appearance of an Arabic edition of the Kitāb al-sìra in that period.

When such an edition appeared in I979, its editor Ismā '̄il al-'Arabī framed his Arabic text as a response to the violence inflicted on it by his French predecessors. In al-'Arabī's eyes, Masqueray and the team of Arabists at the University of Algiers had been possessed by a 'colonial spirit' that rendered them incapable of understanding the text properly. Finally, the second published Arabic edition of the Kitāb al-sira in 1985 speaks to the aftermath of the French colonial project in different ways. 'Abd al-Rahmān Ayyūb framed his edition with an admonishment of the text's publication history in French for more than a century. However, his own project to edit the Arabic text was made possible by a chance encounter with a French colonial official's private archive while he himself was studying in France. At the same time, the tone of his edition of the text speaks to the very different reality and legacy of the colonial project in Tunisia than in Algeria.

The Kitāb al-sirra preserves a medieval textual tradition about the Ibadi Muslim communities of the Maghrib. But as its publication history demonstrates, when medieval Arabic texts or their translations appeared in print in northern Africa in the nineteenth and twentieth centuries, they carried with them much more recent colonial histories. Historians using either Arabic editions or translations of medieval texts published in the colonial-era must recognise and address this history. Abdelmajid Hannoum has demonstrated that in translating medieval Arabic texts, colonial-era historiography in the Maghrib created 
new works that were repurposed to justify the colonial project and its epistemology. I have argued here that like the translation, the publication of these texts must be also situated historically in the context of colonialism. As the example of the Kitāb al-sìra demonstrates, it was as part of the process of colonial knowledge in Algerian production that the manuscripts of medieval texts like it were commissioned, seized, or purchased before then being translated and published in the form of useful knowledge. Histories drawing from these medieval texts in northern Africa must engage with their colonial pasts and grapple with the reality that they were not merely published in the colonial period but were themselves products and tools of colonial knowledge production. 